\title{
ICT impact on socio-economic conditions of rural Bangladesh
}

\author{
Atiqur Rahman ${ }^{1,4, *}$, Mohammad Nayeem Abdullah ${ }^{2,4}$, Amran Haroon ${ }^{1,4}$, Rahat Bari Tooheen ${ }^{3,4}$ \\ ${ }^{1}$ School of Engineering and Computer Science \\ ${ }^{2}$ School of Business \\ ${ }^{3}$ School of Environmental Science and Management \\ ${ }^{4}$ Independent University, Bangladesh Chittagong (IUBC), Chittagong, Bangladesh
}

\section{Email address:}

arahman@ctg.iub.edu.bd (A. Rahman), nayeem30@yahoo.com (M. N. Abdullah), amran@ctg.iub.edu.bd (A. Haroon), sony_tooheen@yahoo.com (R. B. Tooheen)

\section{To cite this article:}

Atiqur Rahman, Mohammed Nayeem Abdullah, Amran Haroon, Rahat Bari Tooheen. ICT Impact on Socio-economic Conditions of Rural Bangladesh, Journal of World Economic Research. Vol. 2, No. 1, 2013, pp. 1-8. doi: 10.11648/j.jwer.20130201.11

\begin{abstract}
Information and Communication Technologies (ICTs) in a relatively short period of time of our planet's history have had a major transformative impact across all strata of society. In the study, four different villages (520 respondents) from four districts of Bangladesh have been selected to find out how ICTs played a catalytic role in dissemination of information, knowledge transfer, healthcare, capacity building and improved governance and the data were collected during December 2011 to February 2012. The study revealed that factors like social security, rural economy, health care facilities, women empowerment, disaster and emergency response etc. are very much reshaped and influenced by ICTs in Bangladesh as identified in other developing countries.
\end{abstract}

Keywords: ICT, Bangladesh, Socio-Economic Factors, Rural Community

\section{Introduction}

Information and communication technology (ICT) comprises of three separate words -information, communication and technology. Information is defined as any kind of message; written, audio, visual or audio-visual through which a person gets knowledge about a new person, place, thing, situation, or environment. Similarly, communication is the way of transferring such message to others which needs a medium, a clear message, and sender and receiver. Information and communication technology is the use of modern technology to aid the capture, processing, storage and retrieval, and communication of information, whether in the form of numerical data, text, sound, or image [1]. The daily work of the governmental and the private postal services have been greatly shared by internet services - the latest breakthrough in the area of information and communication and the short messaging services through mobile telephony. Information and knowledge are critical components of poverty alleviation strategies, and ICTs offer the promise of easy access to huge amounts of information useful for the poor [2]. The present nature, trend and pace of development around the globe have justified that countries and individu- als without access to information are resource poor. The vast majority of poor people lives in rural areas and derives their livelihoods directly or indirectly from agriculture and therefore, support for farming is a high priority for rural development [2]. However, many developing countries have not taken up Information and communication technologies (ICTs) to the fullest possible extent as a means of reaching increased socio-economic development by entering the knowledge economy [3]. In contrast to the developed countries that have been steadily capitalizing on the rapid pace of ICT, a large number of developing countries, particularly low-income countries have failed in the adaptation of these technologies thus contributing to the "digital-divide "between the developed and developing countries [3].

Rural people in Bangladesh have limited access to resources and public spheres due to their socio -economic situation. The rural people suffer from severe discrimination, due partly to lack of access to information. ICT are that potentially can reach rural people and address their knowledge and information needs. Considering this scenario, the aim of this paper is to explore the ICT impact on the socio economic development of villagers in Bangladesh. Section 2 of this paper focused on literature review to find out the gap 
of the research in Bangladesh context. Section 3 draws idea about sampling and methodology. Section 4, 5 and 6 draws a picture about ICT usage and awareness as well as current statistics of Bangladesh. Section 7 describes various impacts on rural people on the basis of survey. At the end of this paper (section 8), conclusion have been drawn.

\section{Literature Review}

A prevalent belief that policy makers and managers in developing countries should focus on achieving pervasive ICT so that societal benefits will permeate to equivalent degrees of saturation as in developed countries [4], has led many developing countries to increasingly adopt ICT for achieving enhanced socio-economic development [5]. It is believed that there is a direct social and economic value of ICT $[6,7]$. Most developing countries have used ICT to improve results in productivity, increase efficiency of operations and effectiveness, strengthen management and administrative functions, improve market performance and increase business competitiveness [8]. Therefore, ICT is recognized as a means to achieve more efficient socio-economic development in the developing countries [9]. Moreover, ICT is often identified as the key to the re-invention of the governments in developing countries in a liberalized market, following failures in the state bureaucratic models of socio-economic development [10]. For example, ICT can facilitate economic development by availing of information to make choice of development priorities easier and to plan and manage development activities better [5]. Many developing countries such as India have made economic management their prime agenda and use opportunities provided by the ICT to overcome the problems of rural poverty, inequality, and environmental degradation [11]. In these countries, it is believed that development of information systems such as Document Management, Electronic Data Interchange, Group Ware for computer supported group work, and Internet and intranets can lead to innovative administrative information systems, improved service quality, more effective planning and thereby becoming a means of empowering citizens [11],[12], [13].

Bangladesh experiences reduction poverty on one hand and increase in inequality among rich and poor on the other. According to HIES 2005 [14] the head - count rate or incidence of poverty using the upper poverty line was at $40 \%$ national, $43.8 \%$ rural, and $28.4 \%$ urban. However, according to HIES 2005 the national income Gini co - efficient, a measure to assess income inequality, shows an increase from 0.451 in 2000 to 0.467 in 2005 , mostly because of increasing rural inequality.

In this backdrop, scope of individual access to ICTs is limited to a vast majority of the population in country of 145 million. Access to information is a dimension of access to resources, lack of which is the cause for poverty. Public access information venue, thus, is an important resource in the poor rural settings for accessing information, which may help improving livelihood of rural poor people. In assessing the public access to ICTs in the country, the study identified users and non - users of ICTs (at individual level and through public access venues) with different social economic status, i.e., both poor and non - poor. The poor people, identified in the study are those, whose daily income is less than 2 USD.

In Bangladesh, while [15] and [16] have conducted their studies on empowerment and poverty reduction through Village Pay Phone (VPP) scheme which is part of ICT program of Grameen Bank, the village-based micro-finance organization respectively; the research of [1] has focused on the role of Pallitathya Kendra (Sustainable Rural Livelihood Information Network) in poverty reduction. Reference [15]carried out their study in 20 different locations of their project area found positive impacts of VPP in most areas that were studied. According to them, the most pronounced impacts of VPP were found with regard to a general reduction of transaction costs and uncertainty (reduced need for travel, quicker access to information, and more choice) and in reducing the isolation of many villages [14]. They have further explored that, for women the VPP was an important channel for family contacts and communications, especially with husbands living abroad as migrant workers; otherwise, the VPP has had little impact on gender relations (ibid). Therefore, their study has focused on the usefulness of the mobile phones in the project area of VPP of Grameen Bank.

Eighty percent of Bangladesh's population lives in rural areas, often accessible only by unpaved, poorly maintained roads or by river transport. As a result, sending agricultural produce to markets, seeds and fertilizers to farms, children to school, and family members to health clinics, is time consuming, expensive, and oftentimes impossible during the rainy season. With access to information via ICT applications, farmers, fishermen and herders can make informed decisions around supplies, prices, markets, and rural services which directly affect their livelihood.

The importance of gathering, storing and disseminating agricultural experiences and indigenous knowledge cannot be overstated; particularly those practices dominated by women, as men and women may possess different information. Traditional methods of disseminating information in rural areas have been through Rural Community Based Organizations (RCBOs). However, RCBOs are becoming increasingly information poor as they tend to lack technical information compared to organizations operating from major district towns or urban cities. There is also a paucity of relevant information available, particularly accessible content, since many village members are illiterate or have low literacy. Furthermore, RCBOs are increasingly excluded from information published on websites by institutions, donors and the government. In response to this knowledge gap, the Intermediate Technology Development Group (ITDG) in Bangladesh has been working since 1995 to strengthen the capacity of over twenty selected RCBOs to manage and support the enterprise initiatives of their beneficiaries. Through the introduction of ICT applications, 
RCBOs have gained considerable knowledge in operating information enquiry services, developing micro-enterprise information, and disseminating relevant business information to rural communities.

Agriculture and natural resource-based activities can gain from the introduction of ICT applications and use. For example, developing a software database of natural farming techniques, seed usage, and local/native flora and fauna can centralize and codify knowledge on local practices such as crop production, rotation and seed saving rates. By creating web-portals or "virtual" groups/coops in rural areas, or by augmenting the ICT capacity of RCBOs, ICTs can be also be used by agriculture and natural handicraft producers to negotiate prices, disseminate information, develop marketing linkages, or interact with different producers/suppliers.

In Bangladesh, any comprehensive study regarding ICT and socio economic impact was not found. This paper aims to draw a holistic picture based on sample study based on villages in Bangladesh to make a conclusion regarding ICT policy and socio economic impact in Bangladesh.

The objectives of paper are stated as follows.

To have a snapshot regarding ICT coverage and awareness in rural Bangladesh.

To generate an idea how ICT has an impact on rural communities.

To measure the impact on rural communities in regards to socio economic factors like social security, rural economy, health care facilities, women empowerment, disaster and emergency etc.

\section{Study Method or Methodology}

The primary goal of the survey was to extract maximum accurate general feedback in detail from a number of rural communities that covers most of the regions of Bangladesh. It might be of importance to note how the questionnaire for this survey was developed. A draft questionnaire of this particular survey was developed initially by the concerned researchers. The questionnaire was then shared with additional related researchers and academics and in this case inputs from renowned consultants were also taken into consideration. A draft final questionnaire was prepared for a sample survey in more than one focused region. The questionnaire was then finalized with necessary crucial modifications after pre-testing.

It should be mentioned here that anticipating the importance of accurate information on the use of ICT at the household level a total of thirty questions were included on ICT in the survey. The questions focused on the use of fixed telephone, mobile phone, computer, email and internet facilities including offered services based on those technologies. It was a large survey with a long questionnaire. The inclusion of thirty questions highlights a full effort to conduct a survey especially on ICT.

A total of four different regions of Bangladesh were selected to conduct the survey. East Shikarpur village from Chittagong district, Raichow village from Comilla district,
Bazua village from Khulna district and Rotonkhali village from Rangpur district were selected for this particular survey. A total of sixteen volunteers forming four different groups interviewed overall 520 individuals from those areas filling up separate questionnaire for each person as a part of a large field trip undertaken from December 2011 to February 2012. Qualitative research approach was applied including techniques like focused group discussion and individual activity observation were also applied to make the result of the study interpretive [15]. The sample size was not pre-determined; however, data were gathered from maximum possible participants and secondary sources during the month long stay in each village forming a rich data set. Raw data from the completed questionnaires were then collected and put in to customized excel database sheets to construct necessary tables for final data analysis. Thematic analysis [17] enabled this research to identify themes from data.

\section{ICT Coverage in Rural Bangladesh}

Unlike any other technology, acclimatization to mobile phone usage in general people is mostly dissimilar to their acquired literacy level. Mobile phones with their built in friendly operability have a distinct eminence of becoming familiar in a rapid manner. This is why in comparison to many other ICTs, mobile phone adoption trends have evolved in a unique fashion - especially in developing countries. It is very important to mention that the other relevant technologies are also availed by mobile phone services especially in rural areas of developing countries whereas a mobile phone costs much less compared to a computer making the technology accessible to the cluster of low income population around the world. In Bangladesh Complex Annual Growth Rate (CAGR) for fixed telephone lines is $10.9 \%$ and for mobile subscriber is $97.8 \%$. The market share of mobile of total telephone in various countries and in case of Bangladesh, the CAGR is $8.6 \%$. These data were extracted from UNESCAP Statistics Division.

Table 1. CAGR country rating of mobile use.

\begin{tabular}{lcll}
\hline Country Name & $\mathbf{2 0 0 3}$ & $\mathbf{2 0 0 8}$ & CAGR (\%) \\
\hline Australia & 72.1 & 105 & 7.8 \\
Japan & 68.1 & 86.7 & 5.0 \\
Republic of Korea & 71.2 & 94.7 & 5.9 \\
Bangladesh & 0.9 & 27.9 & 97.8 \\
Nepal & 0.3 & 11.3 & 105.0 \\
Source. UNESCAP Statistics Division & & \\
\hline
\end{tabular}

Most of the areas of Bangladesh are now in mobile network coverage. There are six mobile operators working in Bangladesh and they have reached in every corner of the country. Grameenphone (GP) has the largest network with the widest coverage in the country. The GP network now covers over 98 percent of the population and over 87 percent 
of the land area [19].

Grameenphone has made major progress with expansion of mobile phones by a village phone program $(270,000$ Village Phone Operators in 50,000 villages). World Bank also helped to support the private telecommunication firms, such as Grameenphone to accelerate the dissemination of mobile phones throughout the country. As of 2011, the project provided mobile phones to over 60 million people, established over 500 Community Information Centers (CIC), and provided the network signal to over 90 percent of the population [16]. The other five operators are Robi, Airtel, Banglalink, Teletalk and Citycell. These five operators are working to reach a similar statistics like Grameenphone in the area of coverage and subscription.

Differential rate and level of distribution in different regions of countries usually results from the collaboration between assorted factors. Given this warning, the extraordinary growth of mobile telephony around the globe has been especially significant in developing countries [19, 20]. In Bangladesh, the growth rate of using mobile phone is very high and it has significant effect on the socio-economic sector of the country.

\section{Current Statistics on ICT Usage in Bangladesh}

It is impossible at this stage to actually come to any conclusion on the current statistics on the usage of ICT at household or individual levels around Bangladesh especially in rural communities. There has not been any attempt found in the country to undertake a comprehensive survey to accurately collect data on the use of different types of ICTs at the household and individual levels. Though a nearly relevant survey namely, "Household Income and Expenditure Survey 2010" (HIES) was conducted by Bangladesh Bureau of Statistics sought information on the use of ICT (use of computer, email, internet, telephone, mobile phone etc.) at the household and individual levels. Their findings on the usage of ICT can be summarized in the Table 1. It can be observed from the table that there has been modest use of ICT in the economy though its use is gradually increasing.

Table 2 reveals an increasing tendency of using computer facilities in the rural areas of Bangladesh. The most prominent information from the survey is that though mobile phone has been introduced in the country in early nineties, there has been substantial growth of mobile phone usage in the rural community along with city dwellers. The use of Internet has considerably increased both in urban and rural areas as focused by that survey. Understandably, the use of the ICT facilities is much higher in urban areas compared to rural areas.

Table 2. Number of Users of Facilities.

\begin{tabular}{lllllll}
\hline Types of Facilities & National & \multicolumn{2}{l}{ Rural } & \multicolumn{3}{c}{ Urban } \\
\hline Year & 2010 & 2005 & 2010 & 2005 & 2010 & 2005 \\
\hline
\end{tabular}

\begin{tabular}{lllllll}
\hline Telephone & 2.07 & 2.87 & 0.70 & 0.33 & 5.79 & 10.36 \\
Mobile Phone & 63.74 & 11.29 & 56.77 & 6.05 & 82.74 & 26.73 \\
Computer & 3.01 & 1.36 & 0.97 & 0.17 & 8.58 & 4.88 \\
E-mail & 1.39 & 0.20 & 0.39 & - & 4.10 & 0.81 \\
\hline
\end{tabular}

Source. Household Income and Expenditure Survey 2005 \&2010, BBS.

There has been rapid growth of use of Mobile phones between 2005 and 2010 . While only $11.29 \%$ of households used mobile phones in 2005 [14], above $63 \%$ in 2010, more than $83 \%$ (Table 2) of households were found to use them in 2010 through the survey conducted for this research.

\section{Overall ICT and Awareness}

In our survey among 520 respondents $56.15 \%$ are male and $43.85 \%$ are female [Table 3]. We have 196 respondents from 18-30 years age group as they represent the young generation. Below 18 Years old population mostly use mobile to spend time while above 18 years old people mostly use it for socialization and business purpose [Table 4]. 18-30 years old group also use it for entertainment purpose [Table 4]. It was very interesting to be found out that above $90 \%$ people are inclined to ICT facilities for their daily communication necessities. In rural areas, ICT is not at all limited to mobile phone calls only (above $90 \%$ ), rural community has strong users of mobile internet (28.5\%) and e-mails (35\%) though computer usage is somewhat limited to below $10 \%$ only because of its high initial cost of buying [Table 5], but other options are less available and less popular. Most striking feature in rural area is that above 30 years old respondents are very careful about misuses of ICT while below 30 years old respondents are less aware of misuse [Table 6]. Overall awareness and usage of cell phones are very high while other medium of ICT usage are not that popular in village context of Bangladesh. Table 7 shows us how ICTs have been treated in rural communities. More than $90 \%$ of them regularly use mobile phones for making calls. $28 \%$ of them use internet and $35 \%$ of them regularly use e-mails while only $9 \%$ of the total respondent use computers at home or outside.

Table 3. Demography of Respondents.

\begin{tabular}{|c|c|c|c|}
\hline \multirow[t]{2}{*}{ Age Group } & \multicolumn{2}{|c|}{ sex of respondents } & \multirow[t]{2}{*}{ Total } \\
\hline & male & female & \\
\hline$<18$ & 68 & 76 & 144 \\
\hline $18-30$ & 111 & 85 & 196 \\
\hline $31-40$ & 75 & 56 & 131 \\
\hline$>40$ & 38 & 11 & 49 \\
\hline Total (\%) & $292(56.15)$ & $228(43.85)$ & $520(100.0)$ \\
\hline
\end{tabular}


Table 4. Reasons behind Mobile Usage.

\begin{tabular}{lllllll}
\hline $\begin{array}{l}\text { Age } \\
\text { Group }\end{array}$ & $\begin{array}{l}\text { Socializing } \\
\text { (Fam- } \\
\text { ly/Relatives) }\end{array}$ & $\begin{array}{l}\text { Business } \\
\text { purpose }\end{array}$ & $\begin{array}{l}\text { Spend } \\
\text { time }\end{array}$ & $\begin{array}{l}\text { Trendy } \\
\text { use }\end{array}$ & $\begin{array}{l}\text { enter- } \\
\text { tainment }\end{array}$ & others \\
\hline$<18$ & $34.80 \%$ & - & $44.20 \%$ & $15.30 \%$ & - & $5.70 \%$ \\
$18-30$ & $38.60 \%$ & $16.70 \%$ & $2.80 \%$ & $3.20 \%$ & $32.80 \%$ & $5.90 \%$ \\
$31-40$ & $65.20 \%$ & $10.60 \%$ & $8.70 \%$ & - & $3.30 \%$ & $12.20 \%$ \\
$>40$ & $50.60 \%$ & $27.80 \%$ & - & - & $5.40 \%$ & $16.20 \%$ \\
\hline
\end{tabular}

Table 5. Preference of different communication methods.

\begin{tabular}{llllll}
\hline E-mail & Cell phones & Internet & Mails & Others & Total \\
\hline 33 & 412 & 25 & 14 & 36 & 520 \\
$6.35 \%$ & $79.23 \%$ & $4.81 \%$ & $2.69 \%$ & $6.92 \%$ & $100 \%$ \\
\hline
\end{tabular}

Table 6. Complains about misuse.

\begin{tabular}{lll}
\hline $\begin{array}{l}\text { Age Group } \\
\text { (in years) }\end{array}$ & Yes (\%) & No (\%) \\
\hline$<18$ & 71.40 & 28.60 \\
$18-30$ & 66.70 & 33.30 \\
$31-40$ & 50.00 & 50.00 \\
$>40$ & 16.70 & 83.30 \\
\hline
\end{tabular}

Table 7. ICT Types \& Usage Rate in Rural areas.

\begin{tabular}{lll}
\hline Type of usage & Yes $(\%)$ & No $(\%)$ \\
\hline Mobile phone calls & 90.50 & 9.50 \\
Mobile Internet & 28.00 & 72.00 \\
E-mail & 35.00 & 65.00 \\
Computer & 9.00 & 91.00 \\
\hline
\end{tabular}

\section{Impact on Rural Communities}

\subsection{Improving Social Security}

Social security is considered to be the composition of social cohesion and healthcare security. There are a number of ways that mobile services can promote cohesion in families and society. For example, a cheap mobile service allows families and communities to remain as a coherent unit when family members are away for long periods. In cases where a family member is abroad either temporarily or permanently it allows the family unit to remain intact as well as generating inbound international call revenues. About 68\% [Table 8] of the interviewed family members endorsed that social bonds have been all time high since the inception of mobile phone in their area. Above 90\% [Table 8] of the families that have a member or more living away or abroad for a long period believe that mobile communication gives them peace of mind and diminishes their concerns about the safety of their close ones living away. Mobile phones help pour harmony in connubial life more than any other communication medium that existed before like postal mails and audio cassettes with recorded voice said 58\% [Table 8] of the respondents. It is also worthy to mention that there are some issues raised by the interviewees about the misusage of mobile phone and other ICT facilities especially in eve teasing, adulteration through internet and other criminal activities like burglary, political killing and uses by muggers. However, the tendency is dominantly limited to the age group below 30 [Table 6].

Table 8. ICT Social benefits.

\begin{tabular}{lll}
\hline Type of Benefit & Yes (\%) & No (\%) \\
\hline $\begin{array}{l}\text { Peace of mind with family } \\
\text { members living abroad }\end{array}$ & 90.50 & 9.50 \\
$\begin{array}{l}\text { Improved social bonds } \\
\text { Improved conjugal harmony }\end{array}$ & 68.50 & 31.50 \\
\hline
\end{tabular}

One of the most challenging jobs for the government and the NGOs in Bangladesh is to cover maximum portion of the rural community around Bangladesh under healthcare facilities. It has been really tough to keep the doctors and supplies available since the government started building rural health centers in early 80s. Grameenphone with their healthcare service (GP Healthline) has proved that every single corner of Bangladesh can be brought under primary health care at a very tiny expense of a voice call. Mobile phone and ICT facilities have also made medical care possible at doorstep through fast communication and over the phone support in primary treatment. Above $67 \%$ of the total samples [Table 9] endorsed that telecommunication itself has helped save their money during taking doctors' appointments and seeking service availability. Further $78 \%$ [Table 9] said yes to the matter of saving time on an extensive level in all those cases. It can be stated without any doubt that mobile phone alone improved the availability of health care service at a great extent in rural areas. Villagers are now well aware of availing a better and cost effective service for them. Seeking a good doctor or getting primary treatment without a visit to a healthcare facility has become a regular scenario in those areas.

Table 9. Benefits of a mobile phone in Health Service.

\begin{tabular}{lccc}
\hline Type of benefit & Yes (\%) & No (\%) & Not Sure (\%) \\
\hline Saves Cost during appointment & 67.30 & 22.20 & 10.50 \\
Saves Cost of Medicine & 58.50 & 23.50 & 18.00 \\
Reduces Frequency of visits & 75.50 & 23.00 & 1.50 \\
Improves service availability & 50.20 & 33.60 & 16.20 \\
Making the Service faster & 78.00 & 13.50 & 8.50 \\
\hline
\end{tabular}

7.2. Reshaping the Rural Economy 
Our study showed that affordable ICT service in rural communities have played a very strong role in improving the economic condition of the population which contributes to the combined rural economy. Mobile communication and ICT by means of mobile phones has vital impact on Gross Domestic Product (GDP) of Bangladesh which has been, and continues to be, substantial. In rural communities, ICT services have contributed to economic development in rural communities via several avenues.

Dealership, Direct employment of the industry and related industries;

Support employment created by operators\& government spending in employment generating activities;

Reducing the role of middleman in the rural market \& supply chain.

Making foreign remittance fast and easy accessible for the rural people.

Induced employment resulting from the above employees and beneficiaries spending their earnings, and creating more employment.

Greater exchange of market information is necessary for trade to flourish. A successful seller in rural area must be fully informed about domestic as well as global trends of the products. ICT usage enables sellers to learn about new product in the market, to anticipate demand for existing and new products; to understand pricing strategies and overall to innovate. Rural community is getting the required information and market prices from the designated portals and websites with the help of entrepreneurs provided by the community information centers (CIC) spread all over Bangladesh which is spread through ICT infrastructure for rural communities.

Table 10 shows more than $70 \%$ think that mobile phone usage alone saving their travel \& communication cost for all daily necessities. Around 50\% people confirms that it is now saving their commodity costs as people are more concerned about price checking now a days. Above $80 \%$ endorsed that ICT is saving their working hours which they can spend in more productive activities which helps improve their economic condition. Table 11 shows that flow of foreign remittance has become easier and faster for the rural community. More than half of the respondents said that they now feel comfortable with the process and time of getting foreign remittance and remittance from other places of Bangladesh. A portion of them are very familiar with the fast cash service like "bKash" and "mobile money" by some of the mobile operators.

Table 10. Economic benefits of a mobile phone.

\begin{tabular}{|c|c|c|c|}
\hline Type of benefit & Yes $(\%)$ & No (\%) & Not Sure (\%) \\
\hline $\begin{array}{l}\text { Saves Emergency } \\
\text { Communication Cost }\end{array}$ & 71.30 & 22.20 & 6.50 \\
\hline $\begin{array}{l}\text { Saves Regular } \\
\text { Communication Cost }\end{array}$ & 68.00 & 14.00 & 18.00 \\
\hline Saves Travel Cost & 73.50 & 20.80 & 5.70 \\
\hline
\end{tabular}

\begin{tabular}{llll}
\hline Saves daily shopping cost & 50.20 & 33.60 & 16.20 \\
Saves working hours & 82.50 & 8.50 & 9.00 \\
\hline
\end{tabular}

Table 11. ICT in foreign Remittance.

\begin{tabular}{llll}
\hline No & Yes & Not Sure & Total \\
\hline 185 & 267 & 68 & 520 \\
$35.58 \%$ & $51.35 \%$ & $13.08 \%$ & $100 \%$ \\
\hline
\end{tabular}

\subsection{Making Women Counted in the Community}

It is worthy to mention that the internationally acclaimed Village Phone Program (VPP) of the help of Village Phone operators is providing telecommunication services in over 85,000 villages in 61 out of 65 districts of the country [18]. With $75 \%$ women operators it was started since the inception of Grameenphone in March 1997, the Village Phone Program is a unique initiative to provide telecommunications facilities in remote, inaccessible rural areas all over Bangladesh. The Village Phones have proven their enormous potential in boosting income of poor households in rural areas, promoting health care, development of agri-business and in the social empowerment of rural women.

A very positive feeling about the ICTs especially mobile phones was found in the survey among women in rural communities. More than $70 \%$ of the women think that since the inception of mobile phones among them, their sense of security has been improved and the mutual relationship among relatives and friends living in distant places is uprising with fast development [Table 12].Above $63 \%$ of the female respondents also supports that ICT is helping women in getting involved with small businesses and trades where 68 percent or more said that they can now act united and raise their voice [Table 12].

Table 12. Women Empowerment.

\begin{tabular}{llll}
\hline Type of benefit & Yes (\%) & No (\%) & Not Sure (\%) \\
\hline Security Improved & 71.30 & 22.20 & 6.50 \\
Allowed to give opinion & 68.00 & 17.50 & 14.50 \\
Helps do Business & 63.50 & 30.80 & 5.70 \\
Improves mutual relation & 73.80 & 16.70 & 9.50 \\
\hline
\end{tabular}

Women are now more self-aware, can easily have access to health care and counseling services, feel comfortable to get involved in small businesses and trading which make them a significant part of rural economy. VPP have created a "phone culture" among women by enabling their access to communication tools from which they might otherwise be excluded. Better availability of communication has also shown that poor, largely uneducated women can master the skills and run a small business. Women phone operators have achieved economic and social empowerment within their households and communities. 


\subsection{ICT in Disaster and Emergencies}

Access to and response time of the emergency services in rural Bangladesh has been one of the toughest challenges for a very long time. Mobile services dramatically improved access to emergency services, which would otherwise only be available the wealthy. It also allows families to stay in touch with each other in the event of natural disasters, keep the communication up with relief providers and obtain information that will allow them to obtain rapid support.

The research found that while mobiles are only one element of a whole array of communications, they are especially effective at disseminating information swiftly to where it is most urgently needed. One of the most consistent messages to emerge was the benefit of the timely spread of information in response to a disaster. Most important is the superior resilience of mobile phones compared to fixed networks and the ability to install new capacity and implement rapidly where needed. Amongst the main conclusions of the study was that using SMS (seldom available on fixed networks) rather than voice is more effective during emergencies. Text messages are more likely to get through (using less network capacity or can be queued and sent when there is free capacity) and ease congestion on the network. This analysis shows that, in the immediate aftermath of a disaster the contribution of mobile is substantial; thanks to the speed with which cellular networks can recover from damage. It is much easier to repair a wireless base station than hundreds of fixed-lines. This was strikingly demonstrated in the speed of restoration of mobile services to customers in the US after Hurricane Katrina.

Our study shows a similar feeling among the respondents especially in Khulna districts where people have experienced natural disasters recently at cyclone "Sidr" in November 2007. About 95\% [Table 13] of the respondents endorsed that they had early warning through mobile phone. Above $76 \%$ and $85 \%$ believe that ICT helped access the relief and it helped make the rescue faster [Table 13]. Because of early warning our fishermen can now take decisions not to go out for fishing. Villagers in coastal areas can take early shelters of government can smoothly activate evacuation plans with the support of the people.

Table 13. ICT at Natural Disasters.

\begin{tabular}{llll}
\hline Type of benefit & Yes (\%) & No (\%) & Not Sure (\%) \\
\hline Early Warning & 95.00 & 0.00 & 5.00 \\
Made rescue faster & 85.50 & 10.00 & 4.50 \\
Helps reach relief & 76.80 & 7.20 & 16.00 \\
Helps in Rebuilding & 58.50 & 30.80 & 10.70 \\
\hline
\end{tabular}

Medical emergency is another issue extensively affected by ICT facilities came out in the study. It was often a challenge for the rural community to get help and arrange necessary transportation or medical support at dire situations. Time is a very important factor in providing those basic supports to them. Government was also struggling to facilitate rural communities with the services and aid. Mobile phone alone brought revolutionary change in the scenario. Table 14 shows that above $85 \%$ of the respondents were benefitted by mobile phones alone during emergencies and about $80 \%$ of them were medical emergencies which are regular for them.

Table 14. Cell Phone used at medical Emergency.

\begin{tabular}{llll}
\hline General & Medical & Not Sure & Total \\
\hline 33 & 412 & 75 & 520 \\
$6.35 \%$ & $79.23 \%$ & $14.42 \%$ & $100 \%$ \\
\hline
\end{tabular}

\subsection{Bridging the Gap with Digital Divide}

Now people, in general, do not have to travel over 30-35 $\mathrm{kms}$ to districts headquarters to get information on education, health, jobs, government services etc. It has saved their time and money thereby reducing risk of travel as well. As the centers are closure to the community, it has created new possibilities for them. Now a days they can open bank account by using mobile, apply for their passport from Upazila head quarter, collect remittances sitting by using mobile. Each and every Upazila headquarter has their full support websites for citizens. Even in 90's it was clearly visible that villages are lagging behind the city in terms of development co ordination, health care facilities, education etc. But now by using Digital devices and with the impact of ICT over all living standards in rural area of Bangladesh is improving and it is helping to bridging the gap between urban and rural area.

\section{Conclusion}

In Sri Lanka, aftermath of the Asian Tsunami, within a day of the disaster, Nokia flew in crews to start the reconstruction of the mobile network. In another day it had rerouted base stations on their way to other destinations, and reconfigured them to fit the pre-existing network. Also on the first day after the tsunami struck, Nokia delivered the first phones and technical support to relief agencies, primarily the Red Cross/Red Crescent. Access to data services encourages local content, allowing users to learn about local services such as healthcare, agro-service, as well as their general standard of education and knowledge in current affairs. Access to data services allows organizations to provide basic information such as protection against dangerous conditions such as avian influenza and other diseases, surgery times and how to obtain vaccinations. Mobile communications provide these capabilities to all sectors of society, whilst fixed services do not. In developing countries, fixed services are generally only available to wealthy individuals and corporations. Given an appropriate policy regime, mobile services can be extended to the whole population and that will contribute to improve all socio economic indicators. Developing country like Bangladesh can use 
ICTs to turn the micro mobility of micro finance in to macro mobility to become a middle income level country from poor level.

\section{Acknowledgments}

The authors thank the village respondents who gave their time and effort in answering the survey questions. The study would be incomplete without their assistance.

\section{References}

[1] Rahman, M. A. (2008). Role of Information \& Communication Technology (ICT) in Rural Poverty Alleviation. A Dissertation submitted to the BRAC Development Institute, BRAC University. December.[Internet] p. 2-47. [Available at. http.//dspace.bracu.ac.bd/bitstream/10361/28/1/Role\%20of $\% 20$ information $\% 20 \% 26 \% 20$ communication $\%$ 20 technology $\% 20 \% 28 \mathrm{ICT} \% 29 \% 20$ in $\% 20$ rural\%20poverty \%20alleviation.PDF] [Accessed on. 13 November 2009]

[2] Harris, R. (2002). A Framework for Poverty Alleviation with ICTs [Internet] Roger Harris Associates, Hong Kong, December. $\quad$ P. 3-64. [Available. http.//www.tanzaniagateway.org/docs/framework_for_pover ty_alleviation_with_ICTs.pdf] [Accessed on. 6 November 2009].

[3] Sofield, T. H. B. (2000). Outside the net. Kiribati and knowledge economy. In F. Sudweeks and C. Ess (Eds.) (2000), Proceeding of the Second International Conference on Cultural Attitudes towards Technology and Communication (pp. 3-26), Perth, Australia.

[4] Talero, E, and Gaudette, P. (1995).Harnessing information for development. a proposal for a World Bank group vision and strategy. Information Technology for Development, 6, 145-188.

[5] Waema, T. M. (1996). Implementation of IT projects and economic development. Issues, problems and strategies. In M Odedra-Straub (Eds.), Global Information Technology and Socio-Economic Development. Nashua. Ivy League, 8-18.

[6] Kling, R. (1996). The centrality of organisations in the computerisation of society. In R. Kling (Eds.), Computerisation and Controversy. Value Conflicts and Social Choices. (2nd ed.). San Diego, C.A. Academic Press, 109-132.

[7] Splettstoesser, Do, and Kimaro, F. (2000).Benefits of IT-based decision making in Developing countries. The Electronic Journal on Information Systems in Developing Countries [On-line].Available http.//www.unimas.my/Fit/roger/EJISDC/ EJISDC.htm, 3.
[8] Avgerou, C. (1996). Transferab ility of information technology and organizational Practice.In M. Odedra-Straub (Eds.), Global IT and Socio-Economic Development. Nashua, New Hampshire. Ivy League Publishing, 106-115.

[9] Samaranayaka, V. K. (1999). Fifty years of information technology. In A. D. V. de.S. Indraratna (Eds.), Fifty Years of Sri Lanka's Independence. Colombo. SLISES, 417-429.

[10] Bhatnagar, S. (2000). Social implications of information and communication Technology in developing countries. lessons from Asian success stories. The Electronic Journal on Information Systems in Developing Countries [On-line]. Available.http.//www.unimas.my/fit/roger/EJISDC/ EJISDC.htm, 1, 1-9.

[11] Kiangi, G. E., and Tjipangandjara (1996). Opportunities for information technology in Enhancing socio-economic development of a developing country. In M. Odedra-Straub (Eds.), Global Information Technology and Socio-Economic Development .Nashua. Ivy League Publishing, 73-81.

[12] Traunmuller, R., and Lenk, K. (1996). New public management and enabling Technologies advanced IT tools. Edward, London. Chapman and Hall, 11-18.

[13] Household Income and Expenditure Survey 2010 (HIES) conducted by Bangladesh Bureau of statistics.

[14] Aminuzzaman, S., Baldersheim, H. \&Jamil, I. (1999). Talking Back! Empowerment And Mobile Phones in Rural Bangladesh. A Study of the Village Pay Phone of Grameen.

[15] Stack, RE 1995, the art of case study research, Sage Publications, Thousand Oaks. Walsham, G 1995, 'The Emergence of Interpretive in IS Research.' Information Systems Research, vol. 6, no. 4, pp.376-394.

[16] Grameenphone Annual Report 2011.

[17] http.//web.worldbank.org/WBSITE/EXTERNAL/PROJECT S/0, contentMDK.21338024 menuPK.64282138 pagePK.4 1367 piPK .279 16 theSitePK.40941,00.html

[18] Castells, M., Qiu, J.L., Fernández-Ardèvol, M. \& Sey, A. 2005. "Mobile Community and Society. A Global Perspective". Annenberg Research Network on International Communication.

[19] Sridhar, K., \& Sridhar, V. (2007). Telecommunications infrastructure and economic growth. Evidence from developing countries. Applied Econometrics and International Development, $7(2)$.

[20] Sinha, C. (2005, October). Effect of mobile telephony on empowering rural communities in developing countries. In International Research Foundation for Development (IRFD) Conference on Digital Divide, Global Development and Information Society (pp. 4-8). 